\title{
Latent Effect of Two Formulated Botanical Fine Dusts on Agrotis ipsilon (Hufn.) Generation
}

\author{
Hassan A. Mesbah ${ }^{1}$, El-Sayed H. Tayeb ${ }^{1}$, Ahmed M. Kordy ${ }^{1}$, Mahasen M. A. El-Shershaby ${ }^{2}$ and \\ Nashaat H. El-Wakil ${ }^{2}$
}

\begin{abstract}
The present study was conducted to evaluate the biological performance of two botanical fine dusts of ploughman's and mexican tea grasses. It was found that the comparative calculated high means numbers of alive larvae in the untreated check $(9.33 \pm 0.33)$ was significantly more or less decreased due to the performance of prepared baits of ploughman's fine dust at concentration rates of 1.0 up to $3.0 \mathrm{gm}$, and distinctly ended by the death of incipient adult-moths of the insect-pest. Versus, the revealed delayed effect of its higher concentration rate of $4.0 \mathrm{gm}$ in the prepared bait, which gave the least detected values of mortality and malformed pupae (2.94 and 2.94\%, respectively), which revealed its adverse biophysiological effects on the development of (f1) generation, followed by complete failure of (f2) $2^{\text {nd }}$ one. Remarkably, all of the tested concentration rates of mexican tea grass fine dust alone (at $0.5,1.0 \& 2.0 \mathrm{gm}$ ) or / and admixed with the fine dust of ploughman's grass at rates of 1:1 or / and 1:2 gm caused rapid and complete failure of development of parent generation after larval treatment. Therefore, the extracted fine dusts for both evaluated natural plants (Mexican tea and ploughman's grasses) could be considered potential alternative to the use of conventional insecticides in the bait, as natural means in $A$. ipsilon control.
\end{abstract}

Key words: $A$. ipsilon, ploughman's, mexican tea.

\section{INTRODUCTION}

The naturally infested plants of field crops with the common noctuid insect pests in the field usually result unlimited yield loss. Amongest, the black cutworm, Agrotis ipsilon (Hufn.) is considered one of the most notorious and destructive phytophagous insect pest in Egypt, not only on cotton but also to many field crops and vegetables (Salama et al., 1970 and Kandil et al., 2003). Where, the larvae on emergence feeds on the epidermis of the leaves, biting the stems of seedling, eating the leaves and sometimes the entire seedling and their habit changes according to their growth. It is a nocturnal insect-pest, as it attacks young seedling of the plants at night and feed on these plants by cutting their stems either below or just above the ground level (Shakur et al., 2007).
The black cutworm control is currently based on heavy use of many insecticides, which damage the environment and/or pose a threat to public health via food residues, ground water or accidental exposure (Hazaa \&Alam EL-Din, 2011). The excessive use of insecticides, particularly those with long residual effect, resulted in several harm to the natural balance between pests and their enemies by killing many non-target organisms, long storage and sometimes very slow degradation of the insecticides and in many cases high toxicity to mammals (Schmidt, 1986). So that, entomologists are concerned to use alternative approaches to control insect pests. One of these approaches is the use of natural pesticides. These materials have a relatively low mammalian toxicity as compared to many chemical pesticides (Ahmed et al., 1984).

Therefore, in recent years, several natural plant extracts and/or products have been considered potential alternatives to conventional insecticides as natural means of pest control (Mesbah, 1985; Mesbah et al., 1985, 1990, 1994 a\&b, 1995, 2004 and Rice and Coats, 1994).

The aim of this research work is to evaluate the toxic efficacy of the prepared baits of fine dusts of two wild grasses either alone or in mixture against the black cutworm, in addition to study their delayed effects on the fitness components of the consequently, raised generations post treatment of parent one.

\section{MATERIALS AND METHODS}

A. Experimental work:

\section{A.1. Source of the black cutworm, Agrotis ipsilon} (Hufn.)

The used larvae of $A$. ipsilon (Hufn.) were obtained as newly deposited eggs from a laboratory culture, Department of Cutworm and Mole Crickets, Plant Protection Research Institute, Agriculture Research Center, Cairo, Egypt.

\footnotetext{
${ }^{1}$ Plant Protection Dep., Fac. of Agriculture, Saba-Basha,

Alexandria University, Egypt

${ }^{2}$ Plant Protection Research Institute, Agriculture Research Center, Giza, Egypt

Received May 10, 2016, Accepted May 30, 2016
} 
Table A. The plant fine dusts and their chemical components

\begin{tabular}{lcc}
\hline Common name & Scientific name & \multicolumn{1}{c}{ Chemical components } \\
\hline $\begin{array}{l}\text { Ploughman's grass } \\
\text { Pluchea (Conyza) dioscoridis }\end{array}$ & $\begin{array}{l}\text { flavonoids, steroids, terpenoids and tannins in both } \\
\text { extracts. Alkaloids were detected in traces }\end{array}$ \\
Mexican tea grass & $\begin{array}{c}\text { Dysphania (Chenopodium) } \\
\text { ambrosioides }\end{array}$ & $\begin{array}{l}\text { ascaridole, limonene, p-cymene, á-pinene, myrcene, } \\
\text { terpinene, thymol, camphor and trans-isocarveol }\end{array}$ \\
\hline $\begin{array}{l}\text { The hatched larvae of the black cutworm were reared on } \\
\text { castor oil leaves (Ricinus communis L.) under the higro- } \\
\text { thermic conditions of } 25 \pm 2^{\circ} \mathrm{C} \text { and } 65 \pm 5 \% \mathrm{R} \text {.H., for } \\
\text { many generations to obtain the sufficient number of } \\
\text { insects needed for the experiment. }\end{array}$ & $\begin{array}{l}\text { mill and sieved with a 100-mesh sieve to obtain their } \\
\text { fine dusts are exhibited in Table A (Claus et al., 1970). }\end{array}$ \\
$\begin{array}{l}\text { A.2. Rearing technique: } \\
\text { According to the adopted rearing techniques by }\end{array}$ & $\begin{array}{l}\text { The treatment of the black cutworm with the } \\
\text { prepared baits of the tested natural plant fine } \\
\text { dusts }\end{array}$
\end{tabular}
Beheedy (1990) and Abdel-Mageed (1997), the newly hatched larvae were kept in clean glass jar (1L.) and covered with muslin which fixed tightly by a rubber band and provided daily with new castor oil leaves until the third larval instar. Then they were transferred to clean disinfected and larger glass jars (2L.) to limit or prevent the incidence of larval cannibalism. The bottom of each jar was covered with a thick layer of fine saw dust and the usual rearing technique was performed along the developing stages of $4^{\text {th }}, 5^{\text {th }}$ and $6^{\text {th }}$ larval instars till pupation occurred. The developed pupae were kept in a glass jars with paper towels on the bottoms and covered with gauze until adult emergence. The incipient adult-moths (males and females in ratio 1:1) were transferred to a bigger jar which was supplied with hanged piece of cotton moistened with $20 \%$ sugar solution in the space of the glass jar. Also strips of dark or/and white cloth fixed in the muslin cover of each jar were used as hanging sites for egg deposition by the mated female moths. Swaps of moistened cotton with the sugar solution were replaced every two days. Also, the muslin strips on which the eggs had been deposited were daily collected and transferred to new jars and left up to hatch. The neonates were fed on castor oil leaves and the colony of mass reared larvae was continued as above explained rearing technique. The needed $4^{\text {th }}$ instar larvae of the black cutworm for the initiated treatments were obtained from the colony.

\section{B. The used Natural plant fine dusts and techniques}

The leaves of both selected wild plant species ploughman's grass, Conyza dioscoroidis Desf. (Compositae) and mexican tea grass, Chenopodium ambrosioides L. (Amaranthaceae) were collected from different areas of El-Beheira and left to dry under room temperature; thereafter, introduced into an electric oven at $60^{\circ} \mathrm{C}$ till complete dryness. The dried leaves of each plant species were well crushed by means of an electric

The exhibited amounts in table B elucidate the used components and rates of carrier material and stimulants in preparing the tested baits of each of the evaluated plant fine dusts or/and their adopted mixtures in these tested baits during the study. The evaluated plant fine dusts of each of ploughman's grass, Five concentration rates of 1, 1.5, 2, 3 and 4gm and the mexican tea grass, three concentration rates of $0.5,1$ and $2 \mathrm{gm}(\mathrm{w} / \mathrm{w})$ were added in the prepared bait. While, their tested binary mixtures in the prepared baits was done by admixing the mexican tea fine dust at rate of $1 \mathrm{gm}$ with ploughman's fine dust at 1 and/or $2 \mathrm{gm}$. All of these mixtures were made before adding and mixing with the other used components of the bait. The exposure of the $4^{\text {th }}$ instar larvae to the fine dust bait was performed in plastic pans (10 cm, in diameter), on which the bait was scattered in regular small amounts. Treatments were run in three replicates, each contained 10 larvae. The exposure of treated larvae on the bait extended along the lasted period from the beginning of $4^{\text {th }}$ instar larvae exposure up to the end of the experiment. In general, mortality counts and the investigated parameters of fitness components were recorded post the larval treatment of parent generation, and the existed following generations according to the type of tested plant fine dust to determine the lasted time of the delayed effect till reaching the state of sterile adultmoths and complete failure of development.

\section{Statistical analysis}

All data were Statistically analyzed using Analysis of Variances (ANOVA), which was run to compare the significance of differences between treatments. The least significant differences (L.S.D) were determined according to Duncan (1955). 
Table B. The comparative used amounts of preparing baits for the evaluated plant fine dusts in lab test

\begin{tabular}{lcc}
$\begin{array}{l}\text { Site of } \\
\text { application }\end{array}$ & \multicolumn{2}{c}{ Bait components } \\
\cline { 2 - 3 } & $\begin{array}{c}\text { Carrier material of } \\
\text { course corn flour }\end{array}$ & Water \\
\hline Field & $25 \mathrm{~kg}$ & $20 \mathrm{~L}$. \\
\hline $\mathrm{Lab}$ & $125 \mathrm{~g}$ & $100 \mathrm{ml}$ \\
\hline \multicolumn{3}{c}{$\begin{array}{c}\text { RESULTS AND DISCUSSION } \\
\text { 1. The efficiency of evaluated botanical fine dusts on } \\
\text { the fitness components of the black cutworm, } \\
\text { Agrotis ipsilon }\end{array}$}
\end{tabular}

1.1. Effect of prepared baits of ploughman's grass fine dust on the fitness components of treated $A$. ipsilon parent $(\mathrm{P})$ generation.

The toxicity of each of the tested rates of botanical fine dusts in the prepared baits against the $4^{\text {th }}$ instar larvae of the parent generation was determined under laboratory hygro-thermic conditions $\left(25 \pm 2^{\circ} \mathrm{C}\right.$ and $65 \pm$ $5 \%$ R.H.).

The presented data in Table(1) elucidate the influence of the evaluated baits of ploughman's grass fine dust on the recorded mortalities and development sequence of parent larvae post feeding on the prepared baits. The numbers and the percentages of derived normal and/or malformed larvae, pupae and emerged moths; deposited eggs / female; hatchability and sterility percentages were calculated and recorded.

The tabulated results in Table (1) also show the calculated high mean number of alive larvae in control treatment $(9.33 \pm 0.33)$, which was significantly more or less decreased at the tested concentration rates of ploughman's grass fine dust. The higher mean value of alive larvae was recorded at the less efficient concentration rate of $4.0 \mathrm{gm}$ fine dust $(4.33 \pm 0.88)$ followed by the means numbers of $(3.33 \pm 0.33 \& 2.33$ $\pm 0.33 \& 2.0 \pm 0.58)$ for the tested concentration rates of $3.0,1.5$ and $1.0 \mathrm{gm}$, respectively. While the lowest mean value of $(1.67 \pm 0.33)$ was detected at the concentration rate of 2.0 gm ploughman's fine dust. The higher percentage of larval mortality $(83.33 \%)$ was recorded for the tested rate of $2.0 \mathrm{gm}$, versus the lower mortality value of $(56.67 \%)$ at the used higher concentration rate of $4.0 \mathrm{gm}$ fine dust.

In all run treatments, the mean numbers of resulted pupae were ratherly reduced and ranged from $(0.33 \pm$ $0.33)$ to $(3.0 \pm 0.58)$ pupae, versus, the highest calculated mean number of $(9.33 \pm 0.33)$ pupae in the untreated control. The number of malformed pupae was
Plant fine dust

Tested progressive rates.

$1,1.5,2,3$ and $4 \mathrm{~g}$. ploughman's grass and $0.5,1$ and $2 \mathrm{~g}$. mexican tea grass

1.0 at both the rates of 1.0 and 1.5 gm ploughman's fine dust; slightly increased up to 2.0 malformed pupae at all the other tested rates, compared to the complete absence of malformed pupae in the untreated control (Table, 1).

Comparatively, the highest mean numbers of incipient adult-moths $(9.33 \pm 0.33)$ in the untreated control was progressively reduced up to $2.67 \pm 0.67$ and/or $0.33 \pm 0.33$ at the concentration rates of 4.0 and $1.0 \mathrm{gm}$ fine dust, respectively. These higher rates of dead adult-moths had been reflected on the extracted number of malformed adults of (1.0) detected for the evaluated concentration rates of $3.0 \& 4.0 \mathrm{gm}$, versus the complete absence of malformed emerged adults in the untreated control. (table, 1).

The deposited number of less fertile eggs 252.7 eggs / female and the lowest hatchability of $22.4 \%$ was only recorded for the lone concentration rate of $4.0 \mathrm{gm}$ ploughman's grass fine dust, compared to 428 eggs / female and $95.5 \%$ hatched eggs in the control treatment.

1.2. The delayed effect of tested high rate of ploghman's grass fine dust on the development of consequent resulted generations of $A$. ipsilon from survived parent (p) adult-moths

\section{a) $\mathbf{1}^{\text {st }}$ generation}

The obtained results of raised (f1) progeny (Table, 2 ) showed that the only lower number of emerged adultmoths at the tested high concentration rate of $4.0 \mathrm{gm}$ of ploughman's grass fine dust laid relatively few numbers of fertile eggs; hatched in lower rate of hatchability, equaled only $36.3 \%$, and resembled the raised surviving larvae of (f1). Though, these weakened newly hatched larvae gave a comparative lower mean number of alive larvae $(17.0 \pm 0.41)$ with increased percentage of mortality amounted to (32\%), vice versa, that recorded higher mean number of alive ones $(23.25 \pm 0.48)$ and least percentage of mortality $(7.0 \%)$ in the untreated control. (Table, 2).

The highest average number of resulted pupae (23.0 \pm 0.58 pupae) in control treatment, was comparatively lowered to a mean number of $(16.0 \pm 0.41$ pupae $)$ at that 
tested rate of 4.0 gm ploughman's fine dust which gave also reduced percentages of pupal mortality and malformed pupae $(2.94 \& 2.94 \%$, respectively), lower mean number of emerged (f1) adults (15.5 \pm 0.64 adults), and percentage of adults malformation comprised $(3.13 \%)$. In addition, the delayed effect of ploughman's grass fine dust treatment at the rate of 4.0 gm greatly reduced the number of deposited eggs per female and hatchability $(682.8$ and $36.3 \%$, respectively); in comparison to the higher number of deposited eggs / female and hatchability percentage (1134.8 and $95.5 \%$, respectively) in the control treatment. (Table, 2).

\section{a) $2^{\text {nd }}$ generation.}

The obtained results of unprofitable delayed effect on the biological performance of tested rate of $(4.0 \mathrm{gm})$ ploughman's grass fine dust on the newly hatched immature larvae of $2^{\text {nd }}$ generation, from deposited eggs by the survived adult-moths of $1^{\text {st }}$ one post parent treatment; was apparent and exhibited in table (4). It is clear that there is adverse biophysiological effect on the mean number of survived larvae (17.75 \pm 0.75 larvae), versus the recorded higher average number of alive larvae in the control treatment $(24.0 \pm 0.41$ larvae $)$. That adverse effect was reflected on the higher larval mortality $(29.0 \%)$ against a lowest value of $4.0 \%$ in control treatment.

Moreover, the mean numbers of the resulted pupae and emerged adult-moths reduced (16.75 \pm 0.93 and $15.5 \pm 0.65$ in respect), versus a highest mean numbers of $(24.0 \pm 0.41$ and $23.5 \pm 0.29)$ in control treatment. The numbers of dead and malformed pupae $(1.0 \& 3.0$ pupae, respectively) were observed for that used rate of $4.0 \mathrm{gm}$, versus, the complete absence of dead or malformed ones in the untreated control.

Remarkedly, the fewer number of deposited sterile eggs (11.2 eggs / female) and the complete absence of hatchability was also observed for that used rate of 4.0 gm fine dust in (f2) treatment. Herein, the adverse biophysiological and hormonal effects on the development of survived individuals of $\mathrm{fl}$ generation; was followed by the faster and complete failure of (f2) (Table 3). That failure could be attributed to the cumulative effect of induced recessive lethal genes in both affected sexes of (f1) generation after (p) one treatment and caused unprofitable effects, appeared at the beginning of $\mathrm{f} 2$ generation, (Table, 3 ).

\section{Effect of Mexican tea grass fine dust on the fitness components of reared $A$. ipsilon parent (p) generation.}

The demonstrated results in Table (4), show a lower mean number of alive larvae gained after mexican tea fine dust treatment at the rate of $2.0 \mathrm{gm}(3.0 \pm 0.58$ larvae); it was more or less lowered in case of the other used rates of 1.0 and $0.5 \mathrm{gm}$ fine dust and amounted to $(2.0 \pm 0.58)$ and $(1.67 \pm 0.33)$ larvae, respectively, compared to $(9.33 \pm 0.33$ larvae $)$ for the untreated control. The higher calculated percentage of larval mortality $(70.0 \%)$ was inspected at the evaluated rate of $2.0 \mathrm{gm}$ fine dust, gradually increased up to $80.0 \&$ $83.33 \%$ at $1.0 \& 0.5 \mathrm{gm}$. While, a lower percentageous value of larval mortality $(6.67 \%)$ was recorded for the control treatment.

In all adopted bioassay treatments, the mean number of resulted pupae was ratherly fewer than that of untreated control and amounted to zero at $1.0 \mathrm{gm}$ and $0.67 \pm 0.33$ pupae at 2.0 gm, versus $9.33 \pm 0.33$ pupae in the control treatment. The highest calculated percentage of dead pupae $(50.0 \%)$ was observed at the concentration rate of 1.0 gm Mexican tea fine dust; the lowest one $(20.0 \%)$ was found at $0.5 \mathrm{gm}$. The highest percentage of malformed pupae $(60.0 \%)$ was detected at the lowest used rate of $0.5 \mathrm{gm}$ fine dust, while the lowest one of $50.0 \%$ was recorded for the performed treatment of $1.0 \mathrm{gm}$ fine dust, versus the observed complete absence of dead and malformed pupae in the untreated control.

It was also found that the highest average number of emerged adult-moths $(9.33 \pm 0.33)$ was revealed in the untreated control, versus the distinct absence of incipient adult-moths at $1.0 \mathrm{gm}$ fine dust or/and the lowest recorded averages of $0.67 \pm 0.33 \& 0.33 \pm 0.33$ adult-moths for both evaluated rates of 2.0 and $0.5 \mathrm{gm}$ fine dust, respectively.

Herein, it is clear that all the tested rates of Mexican tea grass fine dust finally, led to the faster and complete failure of the development of parent generation after larval treatment. That detected complete failure of development could be referred to the rapid occurrence of adverse unprofitable biological performance on the resulted pupae and adults; from the survived treated larvae; and appeared due to the cumulative effect of induced recessive lethal genes in both influenced stages after larval treatment with Mexican tea baits. (Table, 4).

3. Effect of the prepared baits of both admixed botanical fine dusts on the fitness component of raised (p) generation of the black cutworm, Agrotis ipsilon

The toxic efficiency of each of the tested rates of admixed mexican tea \& ploughman's grass fine dusts in the prepared baits against $4^{\text {th }}$ instar larvae of $A$. ipsilon was determined under room hygro-thermic conditions of temperature and relative humidity.

The tabulated data in Table (5) declear the toxic effectiveness of the evaluated mixtures of each of mexican tea / ploughman's fine dusts at rates of (1:1) 


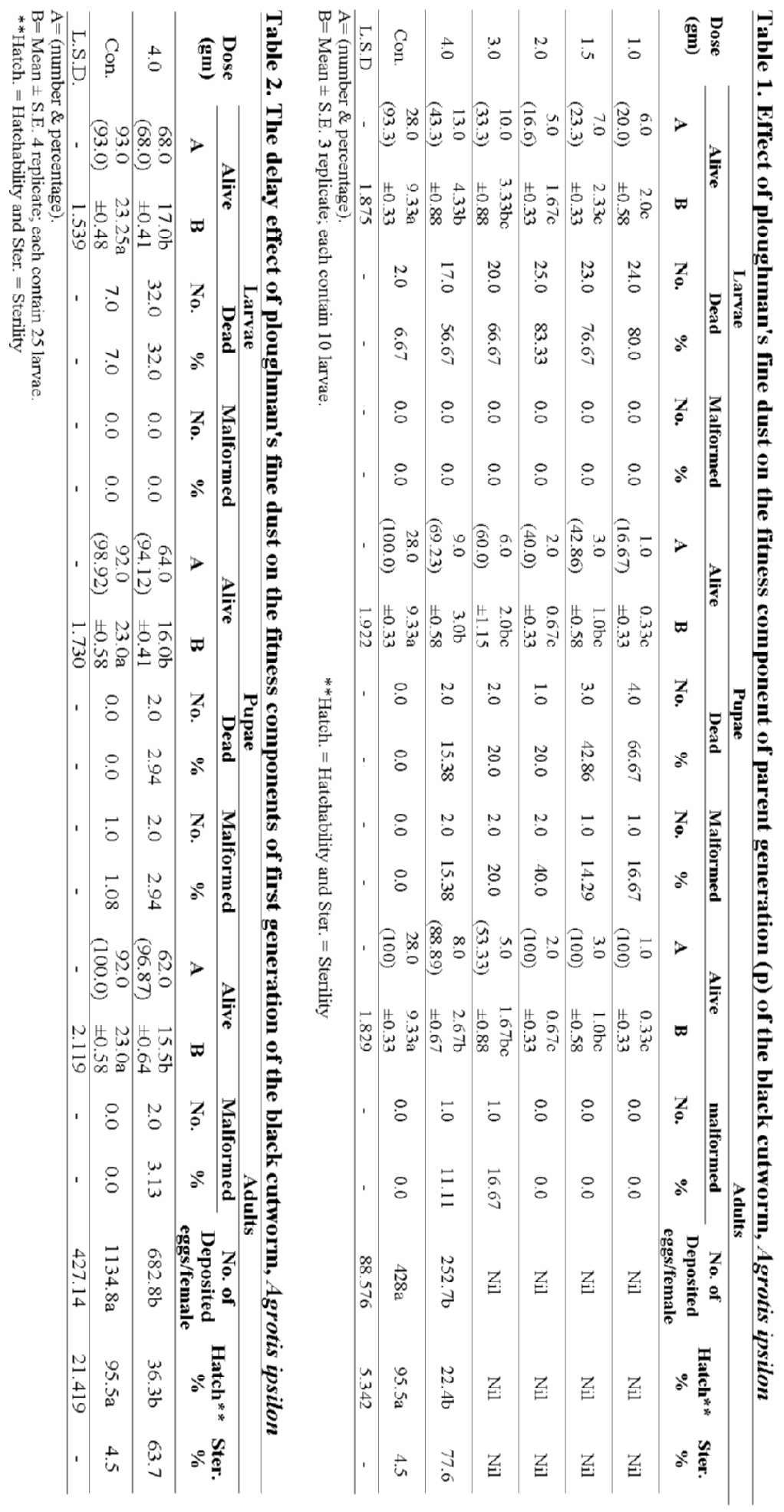




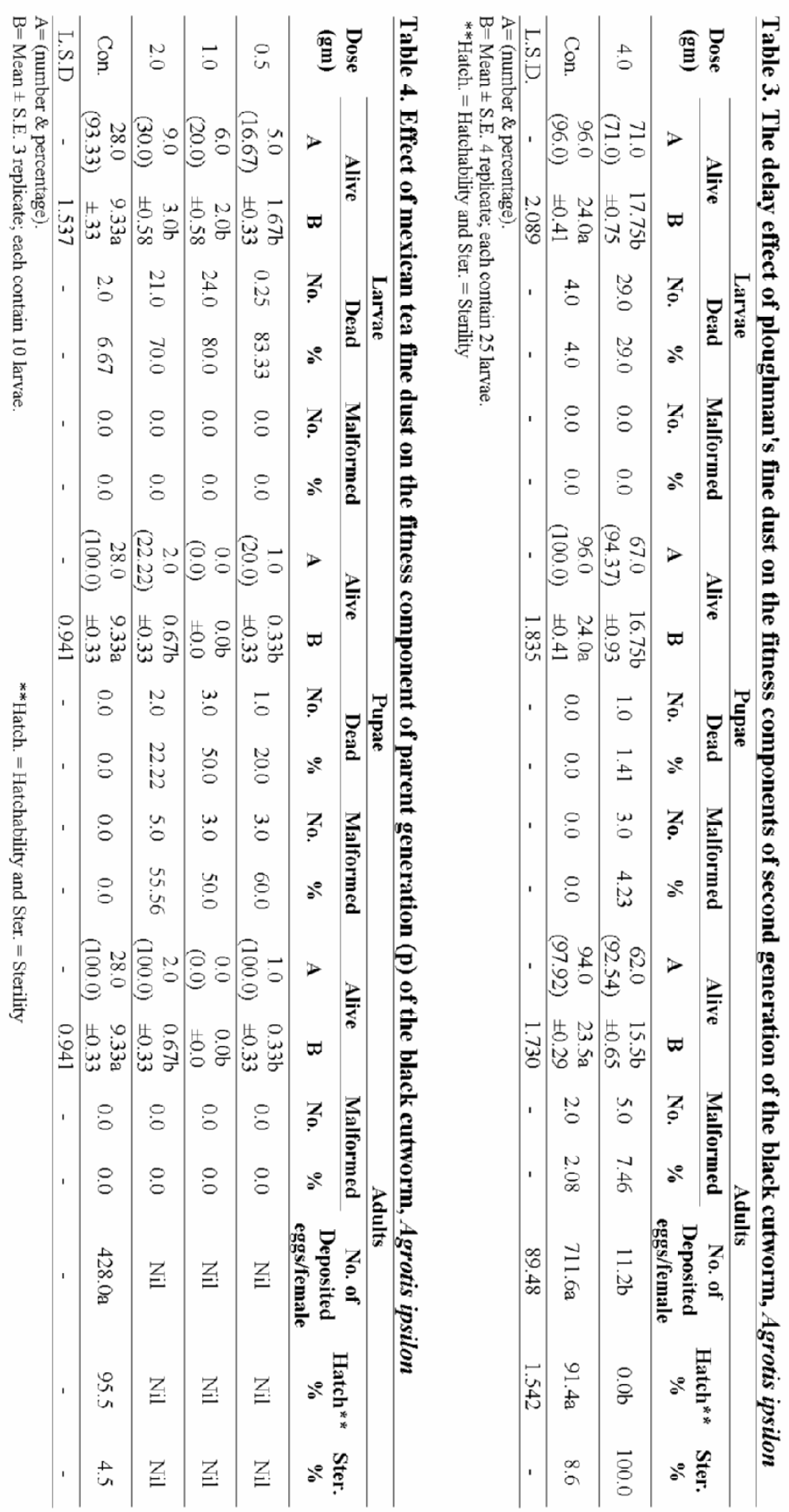




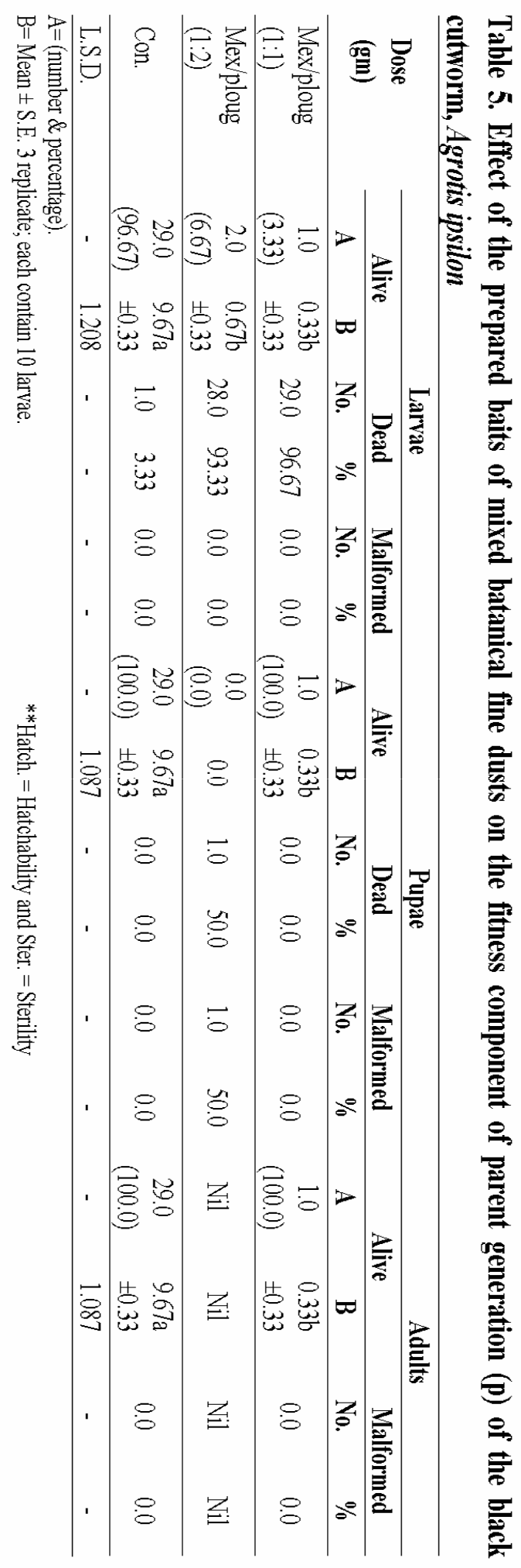


and $(1: 2)$ gm on the developmental sequence of exposed larvae of parent generation on the prepared baits. The number and percentages of resulted normal and / or malformed larvae, pupae, the incipient moths were calculated and recorded.

Data in Table (5) also, declare that both tested rates of evaluated mixtures of tested botanical fine dusts caused significant reduction in the number of alive larvae. Whereas, larval treatment with the baits of mexican tea / ploughman's at ratio rates of (1:1 or/and 1:2) gm gave the lowest numbers of alive larvae $(1.0$ \& 2.0 larvae, in respect) compared with (29.0 larvae) in control treatment, while the baits of both tested rates gave the same negligible value of malformed larvae (nil larvae). Moreover, the absence of raised alive pupae (0.0 pupa) dead and malformed ones was observed for both tested mixture baits of mexican tea / ploughman's at rate of $(1: 1 \& 1: 2) \mathrm{gm}$, versus the highest number of resulted pupae (29.0 pupae) in the untreated control. (Table, 5).

Also, the negligible average number of emerged adult-moths $(0.33 \pm 0.33)$ was observed for the evaluated mixture's bait of mexican tea / ploughman's at rate of (1:1) gm, versus the coincided emergence of adults post treatment with the evaluated bait of mexican tea / ploughman's at rate of (1:2) gm fine dust, compared to $(9.67 \pm 0.33$ incipient adults) in the control treatment.

Identically, the aforementioned results in Table (5) confirm the higher efficient toxicity and unprofitable biological performance of both the tested mixtures of botanical fine dusts on the studied fitness components of treated stages of parent $(p)$ generation. That rapid failure of $(p)$ generation indicates the faster toxic efficiency and occurrence of drastic biophysiological effects during the period of ( $p$ ) generation development. That developmental failure could be also attributed to the commulative effect of induced recessive lethal genes in both affected pupae and adult stages along the extended period of the (p) generation post larval treatment.

Moreover, it could be also seen that the determined faster or slower occurrence of toxic effects and / or drastic biological performance of both the tested rates of evaluated mixtures of the botanical fine dusts, compared to the lonely or individually evaluated fine dusts of ploughman's and mexican tea, may be referred to the probable occurrence of synergistic action.

In concern to our above exhibited results of evaluated botanical fine dusts and their mixtures against the black cutworm, the literary information of numerous conducted research works on the toxic effect and/or biological performance of experimented phytochemicals as essential or volatile oils and/or course and fine dusts against plenty species of insect-pests were mentioned in the works of numerous researches, i.e., Novo et al. (1998) on the lepidopteran insect-pest Anticarsia gemmatalis Hub.; Sharaf El-Din (1998) on the wax moth larvae Galleria mellonella; Parajapati et al. (2003) against the treated pupae of $S$. oblique; Boica junior et al. (2005) on the development of P. xylostella and Barbosa et al. (2011) against the Aleyrodid, Bemisia tabaci; the lepidopteran, Tuta absoluta and some inspected parasitoids and predatory species.

Moreover, Mesbah et al. (2006) studied the efficiency of some plant oils alone and/or combined with different insecticides on the cotton leaf worm $S$. littoralis (Boisd.). They showed that the development of the treated $4^{\text {th }}$ instar larvae was blocked due to the treatment with tested plant oils. With no exception, all the efficiently tested essential and/or volatile oils acted principally as insect growth inhibitors (IGIs) rather than antifeedants causing disruption of the insect development, abnormal larvae, pupae and adults that were lead finally to death.

A similar trend of performed trials on the efficiency of volatile oils and their mixtures on the soft scale insect Saissetia coffen infesting the sago palm, was elucidated by Mesbah et al. (2010). The toxic activity and delayed effects of tested botanical volatile oils (either bioassayed or admixed in the prepared baits) on the following generations (Fs) of the black cutworm $A$. ipsilon, after parents (P) treatment were studied by Mesbah et al. (2014a,b). It was revealed that all the tested oils were found to have more or less toxic activity and drastic effects on the inspected parameters of fitness components of the treated parent $(\mathrm{P})$ generation of the insect, in particular, pupae, emerged adult-moths and laid eggs/female. The assessed unprofitable delayed effects on the going on of the biological performance within the tested insects showed the adverse effects on the fitness components of the consequent generations (Fs) post $(\mathrm{P})$ one treatment with each of the bioassayed oils or/and involved in the prepared baits ; which finally followed by the distinct failure of insect development.

In addition, the biological performance and delayed effects of many botanical fine dusts and natural materials were investigated on the potato tuber moth, Phthorimea operculella (Zeller) (Mesbah et al. 2011a\&2012) and the rice weevil, Sitophilus oryzae (L.) (Mesbah et al. 2011b)

Mohamed (2012) also bioassayed plant extracts of Conyza dioscorides (Barnoof) with two different solvents upon the $5^{\text {th }} \sim 6^{\text {th }}$ instar larvae of $F 1$ generation 
of the black cutworm, Agrotis ipsilon and determined their effects on certain biological aspects and the energy budget of the insect. Data revealed that gamma irradiation when combined with the extract in most treatments significantly higher than the control of reproduction at all treatments (doses and concentrations). The coefficient of metabolizable energy (C.M.E.) not affected at all treatments. The efficiency of storage of ingested energy [E.S.I.(E)] and the efficiency of storage of metabolizable energy [E.S.M.(E)] were between increasing and decreasing when the F1 progeny treated with plant extract alone or combined with the dose 100 Gy while it were significantly increased at all treatments when the dose 150 Gy combined with the plant extract.

\section{REFERENCES}

Abdel-Mageed, A. A. F. 1997. Insecticidal activity of Bacillus Thurigensis and its mixtures with pesticides against Agrotis ipsilon . M. Sc Alex. Univ., Egypt. 118.

Ahmed, S.; M, Grainges.; J. W. Hylin.; W. C. Mitchel. And S. Lit-Singer. 1984. Some promising plant species for use as pest control agents under traditional farming systems. Proc. 2nd Int. Neem Conf., Rausisch-holzhausen, 565580 .

Barbosa, F. S.; G. L. D. Leite; S. M. Alves; A. F. Nascimento; V. A. D'Avila and C. A. Costa. 2011. Insecticide effects of Ruta graveolens, Copaifera langsdorffii and Chenopodium ambrosioides against pests and natural enemies in commercial tomato plantation. Acta Scientiarum Agronomy, 33(1):37-43.

Beheedy, A. A. 1990. Toxicological and histopathological studies on Agrotis ipsilon (Hufn.). Ph. D., Faculty Agric., Alex. Univ., Egypt.

Boica Junior, A. L.; C. A. M. Medeiros; A. L. Torres and N. R. Chagas Filho. 2005. Effect of plant aqueous extracts on the development of Plutella xylostella (L.) (Lepidoptera: Plutellidae), on collard greens. Arquivos do Instituto Biologico, 72(1):45-50.

Claus, E. P.; V. E. Tyler and L. R. Brandy. 1970. Pharmacognosy $6^{\text {th }}$ Ed., Ind. Ed. Lea and febiger, Philadelphia, K. M. Varghese co., 518 pp.

Hazaa, M.A.M. and M.M.S. Alm El-Din. 2011. Synergistic effect of the insect growth regulator, Neporex to gamma radiation on the black cutworm, Agrotis ipsilon. Isotope \& Rad. Res., 43(3), 855-868.

Duncan, D. B. 1955. Mutiple range and multiple F. Tests, Biometrices., 11: 1- 4.

Kandil, M. A; N. F. Abdel-Aziz and E. A. Sammour. 2003. Comparative toxicity of chlorfluazuron and leufenuron against cotton leaf worm Spodoptera littoralis (Boisd.). Egypt. J. Agric. Res., 2:645-661.

Mesbah, H. A. 1985. Evaluation of the potency of the biological compound Dipel against the spiny bollworm Earias insulana Boisd. J. Agric. Sci. Camb., 105: 587-589.
Mesbah, H. A.; A. K. Mourad and A. M. Ebieda. 1985. Toxicological studies of natural phytocompounds. 1: Synergism and Antagonism of pyrethroid orangophosphorous-Volatile oils of ornamental and medical plants against the house fly larvae, Musca domestica, L. Proc. $6^{\text {th }}$ Arab. Pesticide Conf. Tanta. Univ. (1): 423-434.

Mesbah, H. A.; E. H. Tayeb; M. Z. Abdo and Nagda El-sayed. 1990. Toxicological studies of natural phytocompounds 3 . efficiency of some volatile oils on the $4^{\text {th }}$ instar larvae of cotton leafworm, Spodoptera littoralis (Boisd.), J. pest control \& Environ. Sci. vol.2.211-213.

Mesbah, H. A.; E. M. El-Kady and A. S. El-Deeb. 1994a. Toxicological studies of natural phyto-compounds. IV. Effect of synthetic pyrethroids and volatile oils combinations against adults of the house fly, Musca domestica complex. Journal of Union of Arab Biologists 2(A) Zoology 45-59.

Mesbah, H. A.; A. S. El-Deeb; T. Bdr-Sohir and E. M. ElKady. 1994b. The toxic effect of certain phyto-compounds and biological preparations against the adult females of the house fly, Musca domestica L. Annals of Agric. Sci. Moshtohor, 32(1):537-549.

Mesbah, H. A.; E. M. El-Kady and A. S. El-Deeb. 1995. Toxicological studies of natural phyto-compounds. Effect of organophosphorous compounds and volatile oils combinations against adults of the house fly, Musca domestica complex. J. Egypt. Ger. Soc. 16 (E) Entomology 461-476.

Mesbah, H. A.; Farida A. Taman; Aziza A. S. Fata and I. B. Bakr. 2004. Evaluation of some new insecticides, insect growth inhibitors and plant oils against the cotton leafworm and sugar beet fly in sugar beet fields. Alex. Sci. Exch., 25(2):341-351.

Mesbah, H. A.; A. K. Mourad; A. Z. Rokaia. 2006. Efficacy of some plant oils alone and/or combined with different insecticides on the cotton leaf-worm Spodoptera littoralis (Boisd.) (Lepidoptera: Noctuidae) in Egypt. Commun. Agric. Appl. Biol. Sci.,71(2):305-328

Mesbah, H. A.; Nagda A. El-Sayed; A. K. Mourad; Soad I. Abdel-Razak and Samar Abdel-Rahman. 2010. Efficacy of volatile oils and their mixtures against the soft scale insect, Saissetia coffeae (Walker) (Hemiptera : Coccidae) infesting the sago palm, cycas revolute in Alexandria Egypt. Comm. Appl. Biol. Sci. Ghent Univ., 75(3):379389.

Mesbah, H. A.; M. B. El-Kady; R. M. Gouda and G. M. Ibrahim. 2011a. Efficiency of natural plants fine dusts on the fitness components of potato tuber moth Phthorimaea operculella (Zeller) (Lepidoptera: Gelechiidae) 1) Effect of Kamphor and citrus fine dusts. Minufiya J. Agric. Res. Vol. 36(1): 109-124.

Mesbah, H. A.; E. H. M. Tayeb; Nagda A. A. Elsayed; Magda B. A. El-Kady and A. A. A. Greira. 2011b. Biological performance of certain botanical fine dusts, ash and sulphur powder against the rice weevil Sitophilus oryzae (L.) (Coleoptera; Curculionidae). Alex. Sci. Exch. J., 32(2):171-181. 
Mesbah, H. A.; M. B. El-Kady; A. K. Mourad; A. M. Kordy; R. M. Gouda and G. M. Ibrakim. 2012. Efficiency of guva and lemon grass fine dusts on the potato tuber moth Phthorimaea operculella (Zeller) (Lepidoptera: Gelechiidae). Agric. Appl. Biol. Sci.,77(4):699-714.

Mesbah, H. A.; N. A. El-Sayed; M. B. El-Kady; E. H. Tayeb; A. K. Mourad; A. M. Kordy and Z. M. Henaidy. 2014a. Efficacy of prepared baits of lone or/and admixed four botanical oils on the viability of successive raised generations of Agrotis ipsilon (Hufnagel) (Insecta: Lepidoptera: Noctuidae) after treating the parent ones. Commun. Agric. Appl. Biol. Sci., 79(2):185-197.

Mesbah, H. A.; N. A. Elsayed; M. B. El-Kady; A. K. Mourad; A. M. Kordy and Z. M. Henaidy. 2014b. Toxic activity and delayed effects of five botanical oils on the following generations of Agrotis ipsilon (Hugnagel) (Insecta: Lepidoptera: Noctuidae) after parents treatment. Agric. Appl. Biol. Sci.,79(2):129:144.

Mohamed, H. F. 2012. Bioenegetics growth model for the effect of Gamma irradiation and / or plant extract Barnoof on the progeny of black cutworm, Agrotis ipsilon (Hufnagel). Int. J. Mol. Zool., 2(2):13-22.

Novo, R. J.; A. Viglianco and M. Nassetta. 1998. Antifeedant effects of four plant extracts on Anticarsia gemmatalis Hub. (Lepidoptera: Noctuidae). Boletin de Sanidad Vegetal, Plagas 24(3):525-530.
Prajapati, V.; A. K. Tripathi; S. P. S. Khanuja and S. Kumar. 2003. Anti-insect screening of medicinal plants from Kukrail Forest, Lucknow, India. Pharmaceutical Biol., 41(3):166-170.

Rice, J. and J. R. Coats. 1994. Insecticidal properties of several monoterpenoids to the house fly (Diptera: Muscidae), red flour beetle (Coleoptera: Temebrionidae) and southern corn root worm (Coleoptera: Chrsomelidae). J. Econ. Entomol., 87:1172-1179.

Schmidt, G. H. 1986. Pestizide undumweltschutz. Vieweg \& Sohu, Braunschweig, 466 pp.

Sharaf El-Din, H. A. 1998. Studies on the effect of some plant extracts on the greater wax moth, Galleria mellonella L. (Lepidoptera: Pyralidae). Annals of Agric. Sci., Moshtohor, 36(4):2637-2649.

Salama, H. S.;N. Z. Dimetry and S. A. Salem. 1970. On the host preference and biology of the cotton leaf worm Spodoptera littoralis. Z. Ang. Entomol., 67: 261-266.

Shakur, M.; F. Ullah; M. Naem; M. Amin; A.U. R. Saljoqi and M. Zamin. 2007. Effect of various insecticides for the control of potato cutworm (Agrotis ipsilon Huf., Noctuidae: Lepidoptera) at Kalam Swat. Sarhad J. Agric., 23(2):423-426.

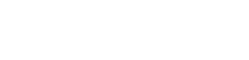

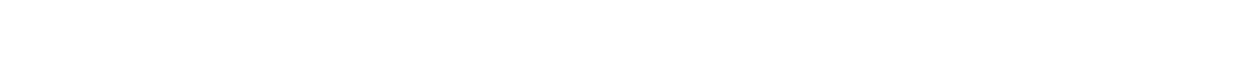

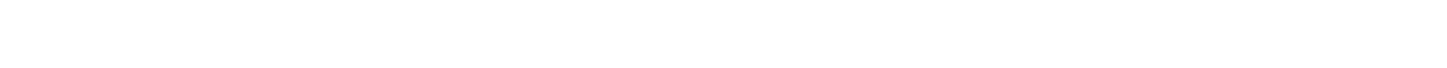

(ع جم) والتى اعطت ألقل شبة ع ذارى ميت ـة وم ششوهة

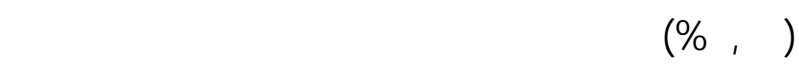

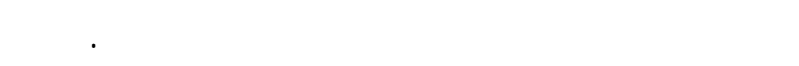

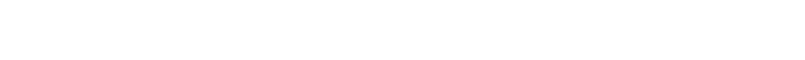

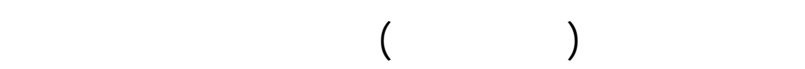

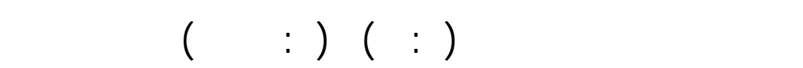
سريع وكلمل لظور جليل الآباء بعدمعلملة اليرقات.

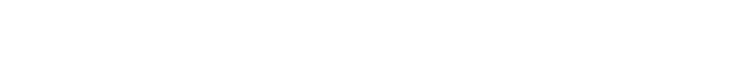
الأسكندرية لقييم الآداء البيولوجى للمسلحق النيق النباتية الناعمة

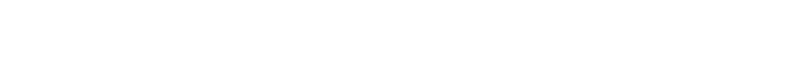

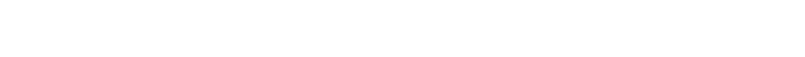

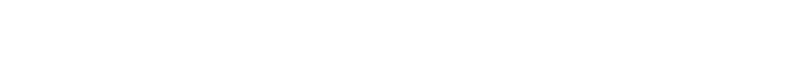

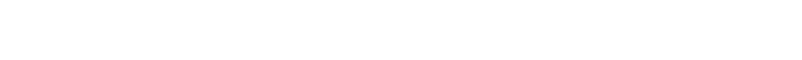
بلغت سب, ب، وذك على عكس المعدلات العالية المستخمة 